\title{
Grzegorz Michalski
}

Uniwersytet Łódzki

\section{Problemy opieki i wychowania w periodyku dla kobiet „Moja Przyjaciółka” (1934-1939)}

W całym okresie Drugiej Rzeczypospolitej dynamicznie rozwijał się rynek wydawnictw periodycznych adresowanych do kobiet. Z badań wynika, że od drugiej połowy lat dwudziestych czasopisma tego typu stanowiły grupę prasową, która wykazywała najwyższy przyrost ${ }^{1}$ zarówno pod względem liczby nowo ukazujących się tytułów, jak i wielkości całkowitego nakładu². Co prawda tematyka kobieca już wcześniej była obecna w pismach ogólnoinformacyjnych, które do swoich tradycyjnych rubryk dołączały dodatki poświęcone przede wszystkim „życiu rodzinnemu”, jednak dopiero wypracowanie przez koncerny wydawnicze wyspecjalizowanej formuły redakcyjnej, obejmującej wszystkie zagadnienia zajmujące kobiety, sprawiło, że zaczęły one doceniać specjalnie do nich adresowany produkt edytorski. Dokonując w 1938 r. klasyfikacji ukazujących się w Polsce czasopism kobiecych, Zofia Zaleska wyróżniła następujące ich rodzaje: pisma organizacji politycznych, pisma literacko-społeczne, pisma stowarzyszeń przysposobienia obronnego, pisma harcerek, pisma stowarzyszeń katolickich, pisma dla gospodyń wiejskich, pisma dla matek, pisma poruszające tematy mody, robót ręcznych, gospodarstwa domowego oraz pielęgnacji zdrowia, pisma dla służących domowych ${ }^{3}$. Szeroki wybór tytułów periodyków dla kobiet oraz zróżnicowanie poruszanych na ich łamach tematów gwarantowały, że każda kobieta mogła odnaleźć pisma odpowiadające jej potrzebom i zainteresowaniom.

Wśród wielu ukazujących się w Drugiej Rzeczypospolitej czasopism dla kobiet zdecydowanie pierwsze miejsce zajmował dwutygodnik „Moja Przyja-

\footnotetext{
${ }^{1}$ O ile w 1926 r. ukazywało się 6 czasopism kobiecych, o tyle w 1935 r. ich liczba wzrosła do 31. Zob. A. Paczkowski, Prasa polska w latach 1918-1939, Warszawa 1980, s. 280.

${ }^{2}$ Zob. Dzieje prasy polskiej, red. J. Łojek, J. Myśliński, W. Władyka, Warszawa 1988, s. 95 i 116.

${ }^{3}$ Z. Zaleska, Czasopisma kobiece w Polsce, Warszawa 1938, s. 114-209.
} 
ciółka”", który w 1936 r. osiagnął blisko ćwierćmilionowy nakład, kilkakrotnie wyższy od podobnych mu periodyków ${ }^{5}$. Wyróżniał się spośród innych magazynów z jednej strony wyraźną użytecznością informacji w codziennym życiu i pełnieniu domowych obowiązków, z drugiej formą przekazu - nie tylko atrakcyjna, ale odwołującą się do najgłębszych pragnień i powszechnych oczekiwań czytelniczek, którym brakowało pisarstwa „od serca do serca”, polegającego na rozmowie $\mathrm{z}$ nimi, a nie na ich pouczaniu ${ }^{6}$. W pierwszym numerze datowanym na 10 stycznia $1934 \mathrm{r}$. redakcja w słowie wstępnym ${ }^{7} \mathrm{w}$ następujący sposób zachęcała do lektury nowego ilustrowanego dwutygodnika:

W obecnych czasach bardziej niż kiedykolwiek występuje konieczność wzajemnego poznawania się, zbliżenia duchowego i korzystania z rad i wskazówek bliźnich. Zdawać by się mogło, że nawał trosk i kłopotów związanych $\mathrm{z}$ walką o kawałek chleba codziennego uczynił z ludzi egoistów, kazał im zamknąć się i zasklepić w ciasnym kręgu własnych zapatrywań. A jednak życie dzisiejsze wykazuje coś wręcz przeciwnego. Znękani ludzie doskonale wczuć się umieją w cierpienia współbraci i chętnie niosą słowa współczucia, pomocy duchowej tam, gdzie tego konieczność wymaga [...] Jednym z głównych zadań pisma naszego będzie gorliwe staranie o nawiązanie serdecznego, silnego i trwałego węzła między kobietami wszystkich warstw i wszystkich zapatrywań $^{8}$.

Tak sformułowanemu celowi pomysłodawcy czasopisma pozostali wierni do ostatniego numeru, który ukazał się 1 września 1939 r. Wzrastającą popularność wśród czytelniczek „Moja Przyjaciółka” zawdzięczała rozbudowującym się z roku na rok działom tematycznym. Początkowe egzemplarze z 1934 r. były treściowo skromne i ograniczały się głównie do przekazu, jak racjonalnie i na wysokim poziomie prowadzić różne obszary gospodarstwa domowego oraz jakie są tendencje w modzie i jak należy elegancko się ubierać. Ale już od drugiego roku ukazywania się rozrastały się stopniowo poszczególne numery i przed samym wybuchem drugiej wojny światowej układały się w przeszło dwadzieścia działów tematycznych. Do najważniejszych należały: „Moda”, „Ogródek”, „Kosmetyka”, „Wieś”, „Dobra Gospodyni”, „Higiena i Zdrowie”, „My kobiety między sobą”. Szczególne miejsce w czasopiśmie zajmowała

${ }^{4}$ Czasopismo było wydawane przez koncern wydawniczy Alfreda Ksyckiego, który miał swoją siedzibę w Żninie. Zob. J. Grabowska, „Moja Przyjaciótka”: ilustrowany dwutygodnik kobiecy 1934-1939, Żnin 1997. Do 15. numeru z 1937 r. wydawcą i redaktorem naczelnym był A. Ksycki, po czym funkcję tę przejęła jego żona Anna Ksycka. Zob. „Moja Przyjaciółka” 1937, nr 16, s. 26.

${ }^{5}$ Nakłady większości nie przekraczały $10-12$ tysięcy egzemplarzy. Tylko nieliczne osiagały nakład oscylujący wokół 50-100 tysięcy.

${ }^{6}$ J. Kowalski, Anna, Fredek i Przyjaciótka, „Wysokie Obcasy” 2008, nr 40, s. 12.

${ }^{7}$ Autorką listu do czytelniczek była pomysłodawczyni czasopisma Anna Ksycka. Zob. J. Kowalski, Anna ..., s. 12.

${ }^{8}$ My - kobiety - między sobq. Z serca do serca - Między nami..., „Moja Przyjaciółka” [dalej - MP] 1934, nr 1, s. 2. 
rubryka pod nazwą „Dziecko”, która została wprowadzona na stałe w kwietniu 1935 r. ${ }^{9}$ jako odpowiedź na licznie kierowane w listach do redakcji prośby czytelniczek, aby więcej w nim miejsca poświęcać problematyce opieki nad dziećmi oraz zasad i metod ich wychowywania. Uruchamiając nowy dział w czasopiśmie redakcja pisała:

Otwieramy go w trosce o to, by nowe pokolenie było zdrowe, pełne sił i zapału do wytężonej pracy. Dlatego też w dziale tym omawiać będziemy wszelkie zagadnienia dotyczące zdrowia, higieny i wychowania dziecka. Specjalna współpracowniczka odpowiadać będzie w tym dziale na wszelkie zapytania Pań Czytelniczek, związane z tą dziedziną ${ }^{10}$.

$\mathrm{Z}$ analizy zawartości wszystkich artykułów na ten temat jasno wynika, że w „Mojej Przyjaciółce” nie tylko udzielano w tym zakresie praktycznych porad, które dla niedoświadczonych matek mogły okazać się nie do przecenienia, ale przede wszystkim formowano nowoczesną świadomość rodzicielską i wychowawczą opartą na najnowszych osiagnięciach w dziedzinie medycyny, higieny, psychologii i pedagogiki. Dzięki tej wiedzy kobiety z różnych warstw i sfer społecznych uwalniały się od odziedziczonej często po rodzicach obiegowej mądrości i stereotypów odnoszących się do wychowywania własnych dzieci.

\section{Porady dotyczące wychowania zdrowotnego dzieci}

Wiele miejsca na łamach „Mojej Przyjaciółki” poświęcono problematyce wychowania zdrowotnego dziecka. Przyjmując założenie, że czytelniczki nie mają wystarczającej w tym obszarze wiedzy, przekazywano wiadomości o etapach i przebiegu rozwoju fizycznego człowieka ${ }^{11}$, a także zalecano wiele czynności wobec dziecka, które zapewnią mu niezbędny i dostosowany do wieku poziom opieki. Porady obejmowały z jednej strony podpowiedzi dotyczące sposobów monitorowania podstawowych parametrów rozwojowych dziec$\mathrm{ka}^{12}, \mathrm{z}$ drugiej natomiast wskazania odnoszące się do organizacji oddziaływań opiekuńczo-wychowawczych.

${ }^{9} \mathrm{~W}$ pierwszym roku ukazywania się „Mojej Przyjaciółki” problematyka dotycząca dzieci koncentrowała się głównie wokół różnych aspektów opieki. Dopiero w kolejnych latach zaczęto publikować artykuły, które podejmowały sprawy wychowawcze.

${ }^{10}$ Zob. MP, 1935, nr 7, s. 103.

${ }^{11}$ Zabkowanie zdrowego dziecka, MP, 1934, nr 17, s. 11-12; Innymi oczami spójrzmy na dziecko, MP, 1934, nr 22, s. 13; Okres zabkowania u niemowlat, MP, 1935, nr 12, s. 183; Gdy dziecko ma roczek, MP, 1935, nr 12, s. 183; Z. Klecanówna, Z „psychologii” dziecka, MP, 1935, nr 17, s. 259; taż, Kilka słów o psychologii młodzieży. Okres młodości, MP, 1935, nr 18, s. 275; Rozwój fizyczny dzieci, MP, 1935, nr 18, s. 279; Rozwój fizyczny dziecka, MP, 1935, nr 18, s. 279; Gdy dziecko ma roczek, MP, 1936, nr 24, s. 531.

${ }^{12}$ Rozwój fizyczny dzieci, MP, 1935, nr 7, s. 103. 
Przekazując czytelniczkom bogaty zasób informacji o istocie i kontekstach pielęgnacji dziecka, zwracano przede wszystkim uwagę na potrzebę stałych zabiegów higienicznych ${ }^{13}$. W przekonaniu autorów artykułów proces ten powinien rozpocząć się zaraz po urodzeniu dziecka i trwać nieprzerwanie do czasu osiagnnięcia przez nie samodzielności. Do najważniejszych obowiązków w tym zakresie zaliczano przeprowadzanie codziennych kapieli, które stanowily podstawowy czynnik zapewniający zdrowie. Uzasadniając ich konieczność, tak pisała na ten temat jedna $\mathrm{z}$ publicystek:

Kąpiel jest nieodzownym warunkiem dla prawidłowego rozwoju dziecka, nie tylko dlatego, że za pomocą jej najłatwiej oczyścić skórę z wszelkich substancji szkodliwych, ale także dlatego, że jest ona doskonałym bodźcem dla wzmożenia rozmaitych czynności ustroju. Wpływa ona korzystnie na ukrwienie skóry i błon śluzowych, a także na czynności serca ${ }^{14}$.

Niezależnie od walorów zdrowotnych regularnej toalety, podkreślano jej dobroczynny wpływ na stan i kondycję psychiczną dziecka. Wskazywano, że dzięki niej ulega zmianie usposobienie i samopoczucie, co pozytywnie przeobraża relacje społeczne, które otwierają szerokie możliwości zaspokajania zarówno potrzeb psychicznych, jak i duchowych ${ }^{15}$.

Do ważnych zabiegów pielęgnacyjnych zaliczano na łamach „Mojej Przyjaciółki" dbanie o odpowiedni ubiór dziecka, który powinien spełniać nie tylko kryteria estetyczne, ale także higieniczne i zdrowotne. Zalecano, aby był on jak najprostszy i niekrępujący ruchów, ponieważ ,dla korzystnego rozwoju kostnego i mięśniowego, i dla wygody lepiej jest, gdy dziecko ma jak najwięcej swobody członków" ${ }^{\text {"16. W }}$ Welu zapewnienia mu komfortu termicznego radzono dostosowywanie odzieży do pory roku i temperatury powietrza. W sposób obrazowy wyjaśniano, że nie wolno przegrzewać organizmu dziecka, że latem należy ubierać je lekko, a zimą ciepło ${ }^{17}$. Przestrzegając przed nieodpowiednim okryciem, które jest szkodliwe dla zdrowia i może doprowadzać do licznych zaburzeń i schorzeń, pisano: „Dzieci są tak samo, jak rośliny w oranżerii wydane na łup różnych chorób, a przede wszystkim cierpi na tym ich rozwój ogólny, który przygotowuje grunt dla rozmaitych dolegliwości"18. Za takie uważano

${ }^{13}$ D. W., Pielęgnowanie dziecka, MP, 1935, nr 19, s. 295; O pielęgnowaniu zębów u dzieci, MP, 1935, nr 14, s. 215; Jak pielęgnować uszy dziecka, MP, 1937, nr 2, s. 38.

${ }^{14}$ H. Muszyńska, Kapiel dziecka i jej znaczenie, MP, 1938, nr 8, s. 210-211.

${ }^{15}$ F. Łuniewska, Kapiel niemowlęcia, MP, 1939, nr 13, s. 387-388.

${ }^{16}$ Jak ubierać dzieci, MP, 1934, nr 23, s. 7-8.

${ }^{17}$ Zbyt ciepte ubranie dziecka powoduje przeziębienie, MP, 1934, nr 1, s. 7; Zdrowie dziecka zależy od matki, MP, 1934, nr 6, s. 15; Jak ubierać dzieci, MP, 1934, nr 23, s. 7; W co ubrać nasze pociechy?, MP, 1935, nr 14, s. 215; Jak ubierać nasze córki..., [w:] Almanach „,Mojej Przyjaciótki” na rok 1936, Żnin 1935, s. 81-82; Jak ubierać naszych synów, [w:] tamże, s. 83-84.

${ }^{18}$ Odzież dziecka, MP, 1935, nr 21, s. 327. 
przede wszystkim stan podgorączkowy, zaburzenia przewodu pokarmowego, brak apetytu i bezsenność.

Często omawianą na łamach „Mojej Przyjaciółki” formą pielęgnacji było zapewnienie dziecku dostatecznej ilości świeżego powietrza oraz możliwości przebywania na słońcu. Przywołując argumenty natury medycznej, zachęcano do takiej organizacji każdego dnia, aby w jego rozkładzie, bez względu na porę roku i pogodę, znalazło się miejsce na spacery ${ }^{19}$, które wzmacniają „odporność i tężyznę oraz dobre samopoczucie" ${ }^{20}$. Nie radzono jednak ograniczania aktywności fizycznej dziecka wyłącznie do tego rodzaju działalności, gdyż dla prawidłowego rozwoju potrzebuje ono także innych typów ruchu. Aby do nich przekonać, dokonano porównania roli, jaką odgrywają niektóre spośród nich w wychowaniu. Pisano:

W grach w odróżnieniu od ćwiczeń gimnastycznych, rozwijają się tylko poszczególne grupy mięśni, pewne narządy, ale dodatnio wpływają na charakter dziecka - pobudzają umysł, dodatnio wpływają na rozwój zmysłów ${ }^{21}$.

W tym kontekście popularyzowano najprzeróżniejsze zabawy i gry, a także ćwiczenia gimnastyczne i różne dyscypliny sportu zarówno letnie, jak i zimowe. Ze względu na nie najlepsze opinie o tych ostatnich, uważanych w społeczeństwie za szkodliwe dla zdrowia młodego organizmu, szczególnie przekonywano do łyżwiarstwa, którego uprawianie z jednej strony dobrze wpływa na rozwój fizyczny, z drugiej - staje się źródłem relaksu przynoszącego zadowolenie i satysfakcję ${ }^{22}$. Aby zainteresować i zachęcić rodziców do podjęcia przez ich dziecko nauki jazdy na łyżwach, opisywano różne jej techniki, omawiano rodzaje potrzebnego sprzętu, opisywano najlepsze miejsca do jazd, a nawet wymieniano elementy stroju, jaki jest zalecany w tym sporcie $^{23}$.

Za jeden $\mathrm{z}$ bardzo ważnych warunków prawidłowej pielęgnacji dziecka uważano zapewnienie odpowiednio długiego nocnego wypoczynku, który ma równie istotne znaczenie, jak racjonalne odżywianie. Biorąc pod uwagę tę prawidłowość dogłębnie informowano matki, jak długo, w zależności od wieku $\mathrm{i}$ indywidualnych potrzeb, powinien trwać sen oraz jakie warunki otoczenia winny być spełnione, aby był on najbardziej wartościowy ${ }^{24}$. Zaliczano do nich przede wszystkim wietrzenie mieszkania, zapewnienie atmosfery spokoju i codziennego ruchu na powietrzu. Spełnienie wszystkich tych wymogów miało

\footnotetext{
${ }^{19}$ Bobo jedzie na spacer, MP, 1936, nr 23, s. 502-503.

${ }^{20}$ M. Łebkowska, Jak należy ubierać w lecie niemowlęta i dzieci?, MP, 1936, nr 12, s. 232.

${ }^{21}$ M. B., O fizycznym wychowaniu dzieci, MP, 1934, nr 24, s. 13.

${ }^{22}$ Sporty zimowe, MP, 1934, nr 23, s. 3; B. Kierzkowska, Dziecko a sport, MP, 1935, nr 5, s. 70 .

${ }^{23}$ Sport tyżwiarski dla dzieci, MP,1936, nr 1, s.

${ }^{24}$ A kiedy dziecko spać nie może, MP, 1934, nr 8, s. 13; Sen dziecka, MP, 1934, nr 16, s. 8-9.
} 
gwarantować, że dziecko będzie „czuło się silne i mocne, zdrowe na ciele i duchu, będzie mieć zdrowy i ładny wygląd oraz dobre samopoczucie i pogodny nastrój" 25 . Z kart czasopisma czytelniczki dowiadywały się, że jeżeli młody organizm „nie ma dostatecznej ilości snu, to nie może rozwijać się należycie ani pod względem fizycznym, ani umysłowym" ${ }^{26}$. Staje się mało odporny, a przez to podatny na wszelkie choroby, co nierzadko przekłada się na zły stan psychiczny i niewłaściwe zachowanie.

Dla redakcji „Mojej Przyjaciółki” zabiegi pielęgnacyjne stanowiły w wychowaniu zdrowego dziecka warunek konieczny, ale niewystarczający. Uważano, że w tym procesie istotną rolę odgrywa właściwe odżywianie, które jest podstawą prawidłowego rozwoju psychofizycznego i zapobiega chorobom. Propagując przygotowywanie posiłków zgodnie z normami dietetyki, zwracano uwagę na ich higienę oraz estetykę. Twierdzono, że:

Każda kobieta powinna znać pewne zasady dietetyki, czyli nauki o odżywianiu, gdyż leży to w interesie zdrowia nie tylko jej, ale wszystkich domowników. Właściwe odżywianie utrzymuje zdrowie i jest jednym z najlepszych środków leczniczych - a jak często grzeszymy zupełną nieznajomością najprostszych faktów z dziedziny chemii kuchennej, nie zdając sobie sprawy $\mathrm{z}$ tego, do jakiego stopnia stan zdrowia, odporność fizyczna i nerwowa oraz zdolność do pracy, zależne są od sposobów odżywiania ${ }^{27}$.

W kategoriach medycznych i psychologicznych wyjaśniano, na czym polega i od czego zależy skomplikowana problematyka braku i nadmiaru apetytu.

Najwięcej informacji zamieszczanych na łamach „Mojej Przyjaciółki” a odnoszących się do odżywiania dotyczyło wczesnego okresu życia dziecka ${ }^{28}$. Wychodzono $\mathrm{z}$ założenia, że $\mathrm{w}$ tym przypadku są najbardziej potrzebne, ponieważ pojawienie się dziecka tak odmienia sytuację w rodzinie, że wszelkie podpowiedzi, także w tym zakresie, są z jednej strony oczekiwane, $\mathrm{z}$ drugiej natomiast ułatwiają i usprawniają rozwiązywanie nowych sytuacji oraz umożliwiają pokonywanie pojawiających się trudności ${ }^{29}$. W przypadku diety dzieci starszych dużą wagę przywiązywano do zapewnienia w niej składników naturalnych. Wspomagając matki licznymi przepisami potraw ${ }^{30}$, Zofia Zawadzka przeprowadzała następujący dowód:

${ }^{25}$ Zapewnijmy dziecku zdrowy sen, MP, 1936, nr 23, s. 502.

${ }^{26}$ Dzieci i młodzież powinny duzo spać, MP, 1938, nr 4, s. 86.

${ }^{27}$ Zob. Almanach „,Mojej Przyjaciólki” na rok 1936..., Żnin 1935, s. 84.

${ }^{28}$ Mleko kozie dla niemowlat, MP, 1935, nr 10, s. 151; Odżywianie dziecka, MP, 1935, nr 24, s. 376; Odżywianie niemowlat latem, MP, 1936, nr 14, s. 286.

${ }^{29}$ D. Wyr., Odżywianie dziecka, MP, 1935, nr 24, s. 376; D. Wyr., Odżywianie dziecka w późniejszych miesiqcach, MP, 1936, nr 2, s. 26.

${ }^{30}$ Alathea, Jarzynowe sałatki w zimie, MP, 1938, nr 3, s. 61; M. Dąbrowa, Dziecinne potrawy, MP, 1936, nr 11, s. 216. 
Latem powinno się wykorzystywać sezon świeżych owoców i jarzyn [...] Jarzyny dzięki swoim solom mineralnym, witaminom i kwasom organicznym oraz swojej zawartości materiału objętościowego, niezbędnego do regulowania procesów trawiennych powinny wchodzić w codzienny skład jadłospisu dzieci, zwłaszcza latem, gdy jest tych jarzyn dużo ${ }^{31}$.

Nie tylko jakość posiłków dla dziecka była przedmiotem rozważań autorów „Mojej Przyjaciółki”. Niemało zainteresowania poświęcono problemowi ich atrakcyjnego wyglądu i estetycznego podania, uważając, że są to zasadnicze czynniki, od których zależy nastawienie do konsumpcji. Wyjaśniano, że brak apetytu u dziecka, choć jest zjawiskiem dość powszechnym, najczęściej nie ma podłoża chorobowego, a przyczyny tego stanu rzeczy tkwią w postępowaniu samych rodziców i innych osób z ich najbliższego otoczenia ${ }^{32}$. Aby nie dopuszczać do takiej sytuacji, sformułowano kilka praktycznych porad. Po pierwsze, „nie należy podkreślać niechęci i uporu dziecka do jedzenia, gdyż to wzbudza w nim gorszy jeszcze wstręt do posiłków"33. Po drugie, nie wolno zbyt pośpiesznie odciagać dziecka od zabawy, ponieważ wywołuje to nadmierny poziom emocji. Po trzecie, należy zadbać, aby dziecko podejmowało wysiłek fizyczny na świeżym powietrzu, bo nic lepiej nie wzmaga głodu niż wyładowanie energii. Po czwarte, podawanie posiłków powinno mieć regularny charakter, bo dziecko „przywyka do pewnego rytmu, z którego wytrącone reaguje utratą łaknienia"34. Po piąte, bezwzględnie trzeba przestrzegać zasady, aby dziecko nie „podjadało" między posiłkami, gdyż rozregulowuje to fizjologię organizmu i często doprowadza do nadmiernego apetytu, który w przyszłości staje się źródłem poważnych zaburzeń zdrowotnych związanych z nadwagą ${ }^{35}$.

Pomocą w wychowaniu służyły także te artykuły w „Mojej Przyjaciółce”, które podejmowały problemy chorób dziecięcych ${ }^{36}$. $Z$ jednej strony dokładnie je opisywano, z drugiej natomiast podpowiadano, co należy robić, aby ustrzec przed nimi dzieci. Przede wszystkim podkreślano potrzebę higieny, której pedantyczne przestrzeganie zapobiega licznym schorzeniom ${ }^{37}$. Zachęcano więc

${ }^{31}$ Z. Zawadzka, Odżywianie dzieci latem, MP, 1938, nr 14, s. 393-394.

${ }^{32}$ Dzieci nie chca jeść, MP, 1934, nr 9, s. 7; Brak apetytu u dzieci, MP, 1934, nr 24, s. 7.

${ }^{33}$ Dziecko nie chce jeść, MP, 1934, nr 20, s. 14.

${ }^{34}$ Dlaczego dziecko nie ma apetytu, MP, 1937, nr 3, s. 62-63.

${ }^{35}$ Dziecko tęgie czy wysmukłe, MP, 1935, nr 9, s. 135; Libeltowa, Dziecko bez apetytu i dziecko takome, MP, 1936, nr 15, s. 312.

${ }^{36}$ Choroba wiosenna, MP, 1934, nr 6, s. 15; Chore dziecko i jego odżywianie, MP, 1935, nr 10, s. 151; O walce z gruźlica, MP, 1936, nr 4, s. 65; Zgubny wptyw przeziębień na organizm dziecka, MP, 1937, nr 3, s. 62; O chorobie czerwiowej u dzieci, MP, 1938, nr 4, s. 86-87.

${ }^{37} \mathrm{~W}$ czasopiśmie postawiono tezę, że ubiegłe stulecie było wiekiem techniki, natomiast obecne jest erą higieny, dlatego zdrowie człowieka, które do niedawna stanowiło wyłącznie sprawę osobistą, przekształciło się w bardzo ważny czynnik życia narodów. W tym kontekście jednym z głównych postulatów zdrowia jest czystość, która nie może być już luksusem, lecz praktyką codziennego życia zarówno biednych, jak i bogatych. Zob. Jedynie czystość i higiena w niemowlęctwie wychować moga zdrowego czlowieka, MP, 1936, nr 6, s. 104. 
do częstego mycia rąk, utrzymywania czystości pomieszczeń, ubrań i pościeli, dokładnego mycia i gotowania produktów spożywczych wykorzystywanych do przyrządzania posiłków ${ }^{38}$. Podkreślano jednak, że same zabiegi sanitarne to za mało, bo nie uchronią dzieci przed zachorowaniami. Odwołując się do osiagnięć medycznych, zalecano podawanie środków wzmacniających odporność organizmu oraz szczepienia ochronne, które stanowią jedną z najbardziej skutecznych metod zapobiegania chorobom zakaźnym ${ }^{39}$.

\section{Wskazania wychowawcze dla rodziców}

Redaktorzy „Mojej Przyjaciółki” dużą wage przywiązywali do właściwych relacji między rodzicami a dziećmi. Zdawali sobie sprawę, że od ich natury i postaci w pierwszym rzędzie zależy skuteczność oddziaływań wychowawczych. Dowodzili, że w podejściu do najmłodszych należy kierować się życzliwością, która sprzyja pojawianiu się podobnych postaw ${ }^{40}$. Jedna $\mathrm{z}$ publicystek tak pisała na ten temat: „Jeśli starsi chcą, aby młodzież była względem nich poprawna, to muszą płacić tym samym i nie mogą ani dzieci, ani młodzieży traktować mniej uprzejmie, niż dorosłych"41. Analizując charakter takich zachowań, odwoływano się do wiedzy psychologicznej i wyjaśniano, że stanowią one rodzaj kapitału na przyszłość, dzięki któremu dziecko będzie nawiązywać bezkolizyjne stosunki z innymi i ułatwiać sobie funkcjonowanie w codziennym życiu $^{42}$. Ponadto, ze względu na brak poważniejszych doświadczeń społecznych, zalecano udzielanie mu niezbędnej pomocy w sytuacjach, w których nie potrafi samo poradzić sobie $\mathrm{z}$ wieloma problemami. Jako przykład wskazywano moment wejścia $\mathrm{w}$ rolę ucznia, kiedy to nowe otoczenie i nowe wyzwania wywołują zazwyczaj zakłopotanie i jawią się w kategoriach trudnych do rozwiązania. W pierwszych latach nauki proponowano, by pilnie obserwować, w jaki sposób dziecko wypełnia w domu obowiązki szkolne. Nie radzono jednak wyręczać go w wykonywaniu zadań, a jedynie wyjaśniać niezrozumiałe kwestie. Twierdzono, że takie nastawienie i postępowanie rodziców sprawi, że, po pierwsze, dziecko będzie traktowało ich $\mathrm{z}$ ufnością, po drugie - zrozumie stawiane wymagania, które mają podstawowe znaczenie w uczeniu się, gdyż już

${ }^{38}$ A. K., W trosce o zdrowie dziecka, MP, 1935, nr 15, s. 231.

${ }^{39}$ Dlaczego należy podawać dzieciom tran?, MP, 1936, nr 22, s. 479; F. Łuniewska, Szczepienia ochronne, MP, 1938, nr 5, s. 113; A. Moczarski, Krzywica u dzieci, MP, 1939, nr 3, s. 65 .

${ }^{40}$ Dziecko i jego otoczenie, MP, 1934, nr 23, s. 3-4; Innymi oczami spójrzmy na dziecko, MP, 1934, nr 22, s. 13; Dziecko pogodne i dziecko ponure, MP, 1934, nr 22, s. 9-10.

${ }^{41}$ Dzieciom należy się uprzejmość, MP, 1937, nr 18, s. 438.

${ }^{42}$ Rodzice jako wychowawcy, MP, 1934, nr 19, s. 9-10. 
na początku kariery edukacyjnej przyzwyczajają do systematycznego i dokładnego odrabiania prac szkolnych ${ }^{43}$. Niezależnie od wsparcia w przygotowywaniu się do lekcji, postulowano utrzymywanie bliskich i regularnych kontaktów ze szkołą, ponieważ przyczyniają się one do lepszego poznania dziecka przez obydwa środowiska oraz pomagają rodzicom i nauczycielom zrozumieć mniejsze lub większe tempo czynionych przez nie postępów w nauce ${ }^{44}$.

W wychowaniu domowym twórcy „Mojej Przyjaciółki” zwracali uwagę na konieczność uspołeczniania dzieci, które rozważano pod kątem jak najszerszego włączania młodego pokolenia w życie wspólnoty rodzinnej. Na pierwszym miejscu stawiano wyznaczenie dziecku stałych obowiązków domowych ${ }^{45}$. Ich spełnianie postrzegano nie tylko jako odciążanie matek od nadmiernego wysił$\mathrm{ku}$, ale przede wszystkim jako źródło wiedzy i umiejętności nieodzownych $\mathrm{w}$ dorosłym życiu ${ }^{46}$. Jednakowe prawa $\mathrm{w}$ tym zakresie przyznawano zarówno dziewczętom, jak i chłopcom. Izolowanie ich od siebie traktowano jako sprzeczne z wynikami badań naukowych, które dokładnie potwierdzały, że koedukacja kształtuje pewność zachowań i „pozwala na poznanie się wzajemne obojga płci [...], może zapobiec na przyszłość wielu, tak częstym nieporozumieniom,

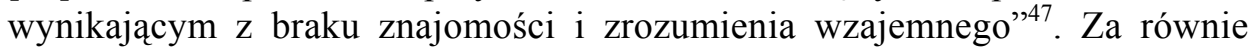
ważny czynnik w uspołecznianiu dzieci uważano wpajanie od najmłodszych lat szacunku dla zwierząt. Podkreślano, że dzięki przebywaniu z nimi kształtuje się poczucie obowiązkowości i odpowiedzialności, umiejętność nawiązywania więzi, a także zdolność wykonywania podstawowych czynności opiekuń$\operatorname{czych}^{48}$.

Specjalne miejsce na łamach „Mojej Przyjaciółki” znalazła problematyka związana $\mathrm{z}$ czytelnictwem dzieci. $\mathrm{Z}$ publikowanych na ten temat materiałów dowiadywano się, że jest ono niezbędnym komponentem wychowania i odgrywa bardzo ważną rolę w kształtowaniu poglądów i przekonań. Podkreślając specyfikę odbioru treści lektury przez najmłodszych, tłumaczono jak dalece jest ona odmienna od percepcji dorosłych. W jednym z artykułów czytamy: „Dorosły do czytania książki przystępuje ze swoim zasobem krytycznych przekonań i poglądów, natomiast dziecko czytając, chłonie wszystko, przekonania autora stają się jego przekonaniami, wszystko przyjmuje bezkrytycznie"49. Aby zapobiec przypadkowemu urabianiu zapatrywań młodego pokolenia, proponowano przyjęcie przez rodziców propagowanej wówczas szeroko na łamach czasopism

\footnotetext{
${ }^{43}$ Rodzice, szkoła i dziecko, MP, 1935, nr 4, s. 51; Powrót do szkót, MP, 1936, nr 17, s. 351.

${ }^{44}$ J. Siwikowa, Stosunek rodziców do pracy szkolnej ich dzieci, MP, 1937, nr 23, s. 556.

${ }^{45}$ Dziatwa a zajęcia domowe, MP, 1935, nr 13, s. 199.

${ }^{46}$ M.Ł., Dziecko pomaga $w$ domu, MP, 1937, $\mathrm{nr} 4$, s. 86.

${ }^{47}$ Fidelis, Temat zawsze aktualny, MP, 1936, nr 1, s. 3.

${ }^{48}$ M. Ł., Nauczmy dzieci kochać zwierzęta i rośliny, MP, 1937, nr 10, s. 239-240.

${ }^{49}$ H. Bartoszek-Zastawniakowa, Co dać dzieciom do czytania, MP, 1938, nr 6, s. 144.
} 
pedagogicznych strategii kierowania czytelnictwem ${ }^{50}$. Najważniejszą czynnością w tym procesie miała być odpowiednia selekcja książek i czasopism, która uwzględnia wiek i zainteresowania dziecka, a także ocenia, czy dana lektura kształtuje stronę intelektualną i uczuciową, a także, czy wzbogaca wyobraźnię, pobudza do myślenia oraz wyrabia język i styl wypowiedzi ${ }^{51}$. W tym kontekście przestrzegano przed lekturą zakazaną, do której zaliczano głównie wydawnictwa o tematyce seksualnej i kryminalnej. Nie ograniczano się tylko do przekazywania ostrzeżeń i formułowania przestróg, pouczano także, które książki są najbardziej wartościowe i pożądane, oraz dlaczego należy zalecać je do czytania ${ }^{52}$.

Zbliżone stanowisko przyjęła „Moja Przyjaciółka” wobec audycji radiowych, cieszących się wówczas dużym uznaniem młodych odbiorców. Wyjaśniając ich niezwykłą popularność, radzono kobietom, aby zwracały baczną uwagę na rodzaj słuchanych przez ich dzieci programów i w razie dostrzeżenia szkodliwych treści szybko interweniowały ${ }^{53}$, ponieważ przekaz radiowy w porównaniu $\mathrm{z}$ treścią książek i czasopism o wiele szybciej i głębiej zapisuje się w pamięci najmłodszych. Problem ten tak tłumaczyła jedna z publicystek:

Młodzież chwyta łapczywie każdą myśl, ideę i przetrawia, kierując się więcej uczuciem i tym samym ulega wpływom, lecz niestety jest wtedy wykorzystywana nie tylko propaganda uczciwa, ale także nieuczciwa - często pozbawiona nudy, łatwo przyswajalna i emocjonująca ${ }^{54}$.

Wychodząc naprzeciw prośbom zgłaszanym w listach do redakcji, wiele artykułów w czasopiśmie poświęcono metodom wychowawczym. Przekonywano, że najważniejszy jest dobry przykład rodziców, szczególnie matek. To właśnie rodziców obarczano odpowiedzialnością za niestosowne zachowania dzieci w domu bądź poza nim. O tym, jak wielkie znaczenie przypisywano sile oddziaływania wzoru osobowego świadczą słowa redaktorki, która nawołując czytelniczki do stworzenia odpowiedniego klimatu w rodzinie stwierdzała:

${ }^{50}$ Zob. np. T. Mikułowski, Uwagi o czytelnictwie młodzieży szkolnej, „Sprawy Szkolne” 1925, nr 1; M. Potworowska-Dmochowska, Kierownictwo literaturq dziecięca, „Ruch Pedagogiczny” 1927, nr 3; J. Gołąbek, Literatura dla młodzieży, „Praca Szkolna” 1928, nr 9; Z. Ziembiński, O ksiażkach do czytania dla młodzieży, „Szkoła Powszechna 1928, z. 2; J. Targowski, Co czyta młodzież, „Gimnazjum” 1936/1937, nr 7-8; J. Bogacz, Czytelnictwo wśród dzieci i młodzieży, „Chowanna” 1938, z. 4.

${ }^{51}$ B. Kierzkowska, Książka a psychika dziecka, MP, 1936, nr 10, s. 191; taż, Ksiażka a psychika dziecka, MP, 1936, nr 18, s. 384; taż, O powstaniu czasopism dziecięcych, MP, 1938, nr 20, s. $547-548$.

${ }^{52}$ J. Mackiewicz-Orłosiowa, Ksiqżeczki dla dzieci, MP, 1938, nr 17, s. 464-465; H. Bartoszek-Zastawniakowa, Wybieramy ksiażkę dla dziecka, MP, 1939, nr 7, s. 194.

${ }^{53}$ Wakacje mtodzieży pod znakiem radia, MP, 1936, nr 14, s. 286-287.

${ }^{54}$ I. K., Radio, prasa, kino a młodzież, MP, 1937, nr 22, s. 533. 
Dlaczego mamy wymagać od synów i córek naszych większej moralności, niż ją sami posiadamy. Odrodźmy się, świećmy przykładem naprawdę dobrym. Niech nasze domy będą przybytkiem prawdziwej kultury duchowej i cnoty obywatelskiej. Wówczas nie będziemy mieli powodów do narzekania na nasze dzieci ${ }^{55}$.

Nie wykluczano również stosowania kar w wychowaniu, dowodząc, że jest to jeden z najlepszych środków szybkiej i skutecznej zmiany kierunku postępowania, i to niezależnie od wieku dziecka. Pomimo że nie niesie on ze sobą efektów ubocznych, apelowano jednak, aby odwoływać się do niego w ostateczności i tylko wówczas, kiedy zawodzą inne sposoby ${ }^{56}$. Poprzez opis konkretnych sytuacji i zdarzeń wychowawczych, zaczerpniętych z codziennych obserwacji zachowań rodziców, pouczano o warunkach stosowania kary, wskazując, że nie może być ona ,zemstą” i powinna nastapić bezpośrednio po złym uczynku, gdyż tylko wówczas dziecko zrozumie, które z zachowań było sprzeczne z oczekiwaniami rodziców ${ }^{57}$. Przestrzegano przy tym przed wymierzaniem kary w uniesieniu emocjonalnym, bo wówczas może być ona niewspółmierna do przewinienia i pojęta w kategoriach krzywdy i niesprawiedliwości ${ }^{58}$. Odpowiadając na pytanie, z jakiego rodzaju kar należy korzystać, przede wszystkim polecano nagany słowne. W przypadku gdyby one nie zadziałały, proponowano izolację dziecka od jego ulubionych przedmiotów lub przyjaciół ${ }^{59}$. Nie wykluczano także kar fizycznych, ale traktowano je tylko jako ostateczne rozwiązanie, które nie może być w żadnym razie nadużywane. Ostrzegano: „Trzeba pamiętać, że dziecko bite już na żaden inny środek wychowawczy nie reaguje. Przy częstym biciu [...] traci lęk przed bólem, a zarazem ambicję i już nie wstydzi się być bitym"60. Nie sprzeciwiając się sporadycznie stosowanym klapsom, które uważano za potrzebne w wychowaniu i szybko oduczające zachowań nieakceptowanych $^{61}$, przypominano o naturze dziecka charakteryzującej się bardzo często negacją i niechęcią do podporządkowania czy wręcz buntem wobec wymagań i oczekiwań. Objaśniano, że w tym przypadku właściwsze jest przyjęcie przez rodziców postawy zrozumienia, tłumaczenia różnych spraw, a nawet pójścia na kompromis, który wytworzy autorytet otwierający porozumiewanie się na zasadzie wzajemnego poszanowania i zrozumienia ${ }^{62}$.

Pochwalanie przez „Moją Przyjaciółkę” stosowania w wychowaniu domowym zróżnicowanego repertuaru kar szło w parze z wyjaśnieniami, jaką rolę

${ }^{55} \mathrm{~F}$. Słaboszewiczowa, Kto ponosi odpowiedzialność za niewłaściwe zachowania się dzieci, MP, 1937, nr 17, s. 414.

${ }^{56}$ M. Benisławska, Bić czy nie bić, MP, 1939, nr 14, s. 416-417.

${ }^{57}$ Czy należy karać dziecko, MP, 1936, nr 6, s. 103.

${ }^{58}$ Zagadnienie kary, MP, 1935, nr 11, s. 167; Jak sqdzić czyny naszych dzieci, MP, 1935, nr 23, s. 360 .

${ }^{59}$ M. S. S., Dzieci trudne do prowadzenia, MP, 1936, nr 18, s. 384.

${ }^{60}$ M. Bonisławska, Bić czy nie bić..., s. 417.

${ }^{61}$ Czy należy karać..., s. 103.

${ }^{62}$ M. Dziubiński, Sqd nad dzieckiem przekornym, MP, 1939, nr 16, s. 476-478. 
w tym procesie odgrywają nagrody. Przywołując wyniki badań psychologicznych wyjaśniano, że każde dobre postępowanie powinno być nagradzane, ponieważ je utrwala i rozwija motywację do jego powtarzania. Polecano głównie uśmiech i pogodny wyraz twarzy matki, a także słowne pochwały, które uczą zachowań, dowodzących konieczności dostrzegania w relacjach społecznych nie tylko tego, co złe, ale także tego, co wyróżniające ${ }^{63}$.

\section{Uwagi o błędach wychowawczych rodziców}

W wychowaniu domowym dzieci dostrzegano wiele nieprawidłowości i niedociagnięć, które wynikały z braku pedagogicznego wykształcenia rodziców, głównie matek. Pomijając te, które należały do mniej poważnych i dających się łatwo wyeliminować bądź naprawić, skoncentrowano swoje zainteresowania na tych trwale i silnie wpływających na osobowość dziecka. Nazywając je błędami wychowawczymi, starano się nie tylko je ukazywać, ale opisywać ich szkodliwość, przekonując, że mogą przyczynić się do powstania trudności i zaburzeń w funkcjonowaniu dziecka w rzeczywistości społecznej. Do głównych błędów wychowawczych zaliczano nadopiekuńczość, która najczęściej przejawia się w nadmiernej trosce o zdrowie dziecka, a także w przesadnym ograniczaniu jego aktywności. W pierwszym przypadku analizowano negatywne konsekwencje przekarmiania i przegrzewania dziecka. Radzono przestrzeganie zaleceń lekarzy i dietetyków, którzy podpowiadali, jaka powinna być struktura i częstotliwość posiłków dla najmłodszych, aby nie doprowadzały one do otyłości wywołującej apatię i stopniową niechęć do podejmowania działań, zwłaszcza fizycznych ${ }^{64}$. W takim samym stopniu oczekiwano wykorzystywania informacji na temat skutków niewłaściwego ubierania dziecka. Zalecano matkom, aby - troszcząc się o właściwy strój- nie kierowały się przyzwyczajeniami lub modą, lecz fachową wiedzą i zdrowym rozsądkiem ${ }^{65}$. W tym drugim przypadku wskazywano na problem wyręczania dzieci w pracach domowych i szkolnych. Opowiadając się zdecydowanie przeciwko takiemu postępowaniu, zwracano uwagę, że doprowadza ono do ukształtowania braku samodzielności i zaradności, a także postawy egoistycznej, która charakteryzuje się koncentracją na własnej osobie i chęcią wykorzystywania innych ${ }^{66}$. Obrazowo ukazując czytelniczkom konsekwencje takiego podejścia do dziecka, pisano:

${ }^{63}$ Jak sqdzić czyny..., s. 360; Czy należy karać..., s. 103.

${ }^{64}$ Libeltowa, Dziecko bez apetytu..., s. 312; Dlaczego dziecko nie ma apetytu..., s. 62-63.

${ }^{65}$ Jak ubierać dzieci..., s. 7-8; M. S. S., Bobo jedzie na spacer..., s. 502-503.

${ }^{66}$ O. Adel, Stosunek dorostych do dzieci i mtodzieży, MP, 1935, nr 22, s. 339; M. Skrzydlewska, Madra i niemqdra miłość macierzyńska, MP, 1937, nr 9, s. 214. 
Pokolenia wychowane w puchu, odgradzane długo od rzeczywistości życia, niezdolne są do walki i do zrealizowania prawdziwie twórczych idei. Nigdy ludzie, którzy późno weszli w życie, nie potrafią być wolni, nie potrafią oswobodzić się z narzuconych im poglądów. [...] Samodzielność młodzieży urabiana powinna być $\mathrm{w}$ domu i w szkole, ale przede wszystkim w najistotniejszej komórce społecznej, jaką jest rodzina. Wychowanie w wartościowym moralnie środowisku rodzinnym jest dla młodych, niedoświadczonych ludzi fundamentem całego przyszłego życia ${ }^{67}$.

Rozważając problem nadopiekuńczości rodziców, podkreślano, że szczególnie często występuje on w rodzinach wychowujących jedno dziecko. Powołując się na badania w tym zakresie, twierdzono, że ten rodzaj postawy może ukształtować osobowość jedynaka na jeden z dwóch typów. Pierwszy, to dzieci zajęte swoją osobą, poważne i zamyślone, mało samodzielne, odznaczające się brakiem odwagi przechodzącym w nieśmiałość, a także zamykające się w swoim świecie wewnętrznym. Drugi, to dzieci zbyt pewne siebie, zarozumiałe i uparte oraz krnąbrne, chcące wszystko naginać do własnych upodobań, co sprawia, że są często przykre dla otoczenia, pomimo że z usposobienia są wesołe i pełne temperamentu. Przedstawiając rodzicom skutki niewłaściwego postępowania wobec jedynaków, jedna z publicystek pisała:

Dziecko zbytnio przez rodziców kochane przyzwyczaja się do tego, że jest ono wyłącznie kochane, wymaga od rodziców z biegiem czasu dowodów tych uczuć, najczęściej nic w zamian nie dając. W ten sposób dziecko przyzwyczaja się do rządzenia, chce rozkazywać, żąda, żeby je słuchano $^{68}$.

Aby zapewnić optymalne warunki do rozwoju społecznego jedynaków, proponowano rodzicom proste $\mathrm{w}$ tym zakresie rozwiązania. Po pierwsze, zapewnianie kontaktów z rówieśnikami poprzez organizowanie częstych spotkań z dziećmi przyjaciół i znajomych. Po drugie, zapisanie do przedszkola, ponieważ przebywanie od najmłodszych lat $\mathrm{w}$ tym środowisku dodatnio wpływa „na rozwój charakteru dziecka" 69 .

Obok nadopiekuńczości, do poważnych błędów wychowawczych autorzy „Mojej Przyjaciółki” zaliczali gderliwość dorosłych. Nie tylko nie zalecali stosowania tej „metody”, ale stanowczo przed nią przestrzegali, ponieważ może spowodować stopniowy zanik autorytetu rodziców i przeniesienie zaufania na zupełnie przypadkowe osoby. Opisując liczne w tym zakresie przykłady sytuacji wychowawczych, wyjaśniano w szczegółach, na czym polegają negatywne strony różnych postaci strofowania, utyskiwania, czy łajania dzieci ${ }^{70}$. Dystans redakcji do takich sposobów postępowania uzasadniano w sposób następujący:

${ }^{67}$ Utatwmy młodzieży walkę o byt, MP, 1935, nr 6, s. 83.

${ }^{68}$ M. Skrzydlewska, Wychowanie jedynaków, MP, 1937, nr 14, s. 332.

${ }^{69}$ M. Skrzydlewska, Wychowanie jedynaków, MP, 1937, nr 15, s. 365.

${ }^{70}$ Zob. np. Nie róbmy z dziecka egoisty, MP, 1935, nr 8, s. 119; Ostrożnie z krytyka, MP, 1936, nr 4, s. 65. 
Zamiast obudzić w dziecku ambicję, przeciwnie, przytłumiają tylko jego wrażliwość. Umysł dziecięcy ma przede wszystkim ogromny instynkt samozachowawczy i z chwilą, gdy coś je zbytnio znuży, broni się samorzutnie; przestaje uważać ${ }^{71}$.

Do kategorii błędów wychowawczych rodziców włączano również pomijanie $\mathrm{w}$ rozmowach z dziećmi problemów związanych z seksualnością. Unikanie ich i traktowanie jako tematu „tabu” uważano za najgorsze posunięcie wychowawcze, gdyż interesowanie się nimi przez dzieci jest naturalną potrzebą rozwojową, która wymaga zaspokajania polegającego na systematycznych i kompetentnych wyjaśnieniach prawidłowości biologicznych zmian w organizmie. Tłumaczono więc czytelniczkom, że pierwsze rozmowy na temat seksualności powinny podejmować $\mathrm{z}$ dzieckiem, gdy samo zwraca się $\mathrm{z}$ tego typu pytaniami $^{72}$. Ponieważ następuje to we wczesnych latach jego życia, radzono udzielanie bardzo ogólnych odpowiedzi, co prawda nie podnoszących żadnych szczegółów, ale w dostatecznym stopniu rozwiewających wszystkie wątpliwo$\mathrm{s}_{\mathrm{ci}}{ }^{73}$. Nie polecano natomiast tego rozwiązania w przypadku dzieci starszych, ponieważ mogłoby ono doprowadzić do poszukiwania innych źródeł informacji i wówczas w najlepszym razie to koledzy bądź koleżanki staną się pierwszymi „nauczycielami”, w najgorszym - niedostosowana do wieku treść książek i czasopism, które wzbudzają „niezdrową sensację i podniecenie" ${ }^{\text {,74 }}$. Podpowiadano nawet, że w pewnym momencie edukacji seksualnej lepiej, by rodzice odstapili od uświadamiania własnych dzieci i zaufali w tym zakresie innym osobom. Tak pisano na ten temat:

Ktoś, kto nie tylko w rozmowie z dzieckiem, ale szczerze w odczuciach swoich z tej dziedziny jest rozsądny i czysty, a zna dziecko i ma nie tylko rodzicielskie, ale i dziecka zaufanie i przyjaźń. Takiemu komuś, gdy wyczuje u dziecka bolesny, przerażony zwrot myśli do rodziców, właśnie łatwiej będzie rzeczowo ich obronić, a rozmowa dużo straci ze swej drażliwości ${ }^{75}$.

Do takich osób zaliczano m. in. nauczycieli szkolnych, którzy dysponują nie tylko bogatą wiedzą dotyczącą płciowości i seksualności człowieka, ale ze względu na swoje pedagogiczne przygotowanie potrafią ją profesjonalnie przekazać młodemu pokoleniu $^{76}$.

Przywiązując ogromne znaczenie do właściwej atmosfery życia rodzinnego, w „Mojej Przyjaciółce” wykluczano możliwość zatajania przed najmłodszymi

${ }^{71}$ M. S. S., Unikajmy gderliwości, MP, 1937, $\mathrm{nr} 4$, s. 86.

${ }^{72}$ F. Stendigowa, Wychowanie dzieci poprzez wychowanie rodziców, MP, 1938, nr 16, s. 439 .

${ }^{73}$ Zob. np. Madra i niemadra miłość macierzyńska, MP, 1937, nr 8, s. 178.

${ }^{74}$ Wu. Zet., Niebezpieczny wiek młodzieży, MP, 1938, nr 14, s. 392-393; W. Zbierowski, Ksiqżka zakazana, MP, 1939, nr 5, s. 126.

${ }^{75}$ M. Benisławska, Uświadomienie, MP, 1938, nr 5, s. 112.

${ }^{76}$ F. Stendigowa, Wychowanie dzieci poprzez..., s. 440. 
spraw, które są ważne dla całej wspólnoty rodzinnej. Zakładano, że jedynym, w pełni usprawiedliwionym, odstępstwem od tej zasady może być sytuacja, kiedy w relacjach między matką i ojcem dochodzi do konfliktów, uważając, że w takich okolicznościach dziecku należy zaoszczędzić nawet najmniejszych wstrząsów spowodowanych niesnaskami i sporami, ponieważ mogą one doprowadzić do głębokich urazów psychicznych ${ }^{77}$. Zachęcając rodziców, aby nie narażali młodego człowieka na traumatyczne doświadczenia, pisano:

Wszelkie starcia między rodzicami odbijają się na delikatnym systemie nerwowym dziecka i na jego wrażliwej duszyczce [...] Prócz tego, dziecko widząc, że ojciec względem matki (lub odwrotnie) postępuje niesłusznie i krzywdząco, bierze stronę skrzywdzonego, a coraz więcej zniechęca się do krzywdzącego, zatracając niejednokrotnie miłość do niego ${ }^{78}$.

„Moja Przyjaciółka” jako jedno z czasopism kobiecych wydawanych w Polsce międzywojennej zyskała w krótkim czasie dużą popularność i przychylność czytelniczek. Sięgały one chętnie po ten periodyk, ponieważ w każdym kolejnym numerze otrzymywały materiały, które rozpatrywały bliskie im życiowo problemy. Do takich - bez wątpienia - należały artykuły na tematy pedagogiczne, które w tym magazynie cieszyły się szczególnie dużą poczytnością. Dowiadujemy się o tym z listów do redakcji. Z ich analizy wynika, że kobiety nie tylko były otwarte na wiadomości o istocie dzieciństwa, ale liczyły także na fachowe podpowiedzi, ułatwiające zrozumienie oraz rozwiązywanie konkretnych sytuacji wychowawczych. W spełnianie tych oczekiwań zaangażowano wielu autorów, którzy legitymowali się specjalistyczną wiedzą w tej dziedzinie i mieli wieloletnie doświadczenie praktyczne. To ich profesjonalizm sprawił, że wszystkie rady i wskazówki czytane były z uwagą i traktowano je jako wytyczne w codziennych kontaktach z dzieckiem.

${ }^{77}$ Zob. np. Trzeba wychowywać rodziców, MP, 1937, nr 2, s. 37; F. Słaboszewiczowa, Kto ponosi odpowiedzialność..., s. 414.

${ }^{78}$ O szczęśliwe dzieciństwo, MP, 1935, nr 17, s. 263. 